Potilaiden suhtautumisesta lailliseen raskaudenkeskeytykseen sekä sen jälkeiseen hedelmöityksen ehkäisyyn

\title{
Mikko Olki.
}

Maassamme suoritetaan raskaudenkeskeyttämislakimme nojalla yli 3000 abortus arteprovocatusta (AA) vuosittain. 1952 oli suoritettujen keskeytysten lukumäärä 3310 . Vuodelta 1953 ei tarkkaa lukua vielä ole saatavissa, mutta se tulee ennakkotietojen mukaan ylittämään 3500 . Lain voimaantulosta lähtien osoittavat ensimmäisten $3 \frac{1}{1} 2$ vuoden AA-luvut jatkuvaa pientä nousua, joten täysin vakiintuneena ei AA-tilannetta meillä vielä voida pitää. Suoritetut tutkimukset (Rouhunkoski-Olki) osoittavat, että keskeytykseen liittyen on $20 \%$ :ssa suoritettu lisäksi sterilisaatio (AAS). Keskimääräisen hoitoajan ollessa AA-tapauksissa 5,9 vrk. ja AAS-tapauksissa 11,5 vrk. vaati näiden hoito vuonna 1952 sairaaloissamme yli 23000 hoitopäivää eli yli 60 hoitopaikkaa läpi vuoden. Yksinomaan tämä, laillisten keskeytysten aiheuttama välitön rasitus maamme lukumäärältään niukoille sairaalapaikoille on erittäin suuri. Pyrkimys AA-tapausten lukumäärän pienentämiseen vähimpään tarkoituksenmukaiseen määräänsä on jo tältä, puhtaasti käytännölliseltä kannaltả tärkeää, puhumattakaan siitä, mikä merkitys tällä pyrkimyksellä on yleisen kansanterveyden sekä yksilön henkisen ja fyysillisen hyvinvoinnin kannalta.

Etsittäessä keinoja tämän päämäärän saavuttamiseksi kiintyy huomio siihen potilasryhmään, jolle on jouduttu suorittamaan AA uusiutuvasti. Kokemus osoittaa, että uusinta-AA:t ovat melko tavallisia ja useimmiten on keskeytyksen syy kerta kerralta sama. Esim. niistä 465 potilaasta, joille Helsingin sosiaalineuvolan lääkä- 
rilautakunta vuosina 1950 - 52 katsoi keskeytyksen aiheelliseksi, on sen jälkeen 115 potilasta $(24,7 \%)$ sosiaalineuvolan kautta uudelleen anonut keskeytystä ja 51 potilasta $(11 \%)$ sen saanut. Suoritettujen laskelmien mukaan muodostavat uusinta-AA:t noin $5 \%$ koko maan AA-luvuista.

Sosiaalineuvolan yhtenä päätehtävänä on selvittää keskeytyksen saaneille potilaille järkevää tilanteen arviointia keskeytyksen jälkeen, saattaa heidät tietoisiksi hedelmöitymisen ehkäisyn välttämättömyydestä sekä eri ehkäisymenetelmistä. Tässä mielessä heitä kehotetaan määräajan kuluttua keskeytyksen jälkeen kääntymään lääkärin tai avioliittoneuvolan puoleen. Lukuisat uusintaAA:t sosiaalineuvolan materiaalissa viittaavat kuitenkin siihen, ettei suuri osa potilaista sittenkään kykene, syystä tai toisesta, ehkäisymenetelmiä käyttäen huolehtimaan syntyvyydensäännöstelystä.

Saadaksemme käsityksen siitä, miten potilaat suhtautuvat raskaudenkeskeytykseen sen tapahduttua sekä välittömästi sitä seuraavaan aikaan, jolloin uuden raskaudentilan alkaminen poikkeuksetta on heille vahingollinen, olemme Helsingin sosiaalineuvolassa suorittaneet jälkitutkimuksen osalle niistä potilaista, jotka neuvolan kautta ovat saaneet myönteisen päätöksen keskeytyspyyntöönsä ja joille keskeytys myös on suoritettu.

\section{A ine is to}

Aineiston muodostaa 100 helsinkiläistä potilasta, joille Helsingin sosiaalineuvolan lääkärilautakunta 1. VIII. $50-31$. X. 52 välisenä aikana on katsonut aiheelliseksi puoltaa raskaudenkeskeytystä ja joille tänä aikana on suoritettu keskeytys. Kyseessä olevana aikana on sosiaalineuvolan kautta myönnetty AA kaikkiaan 206 helsinkiläiselle potilaalle, joten aineistomme käsittää noin puolet koko neuvolan pääkaupunkilaismateriaalista. Potilaita, joille keskeytyksen yhteydessä on suoritettu sterilisaatio, ei ole huomioitu tutkimuksessa.

Jälkitutkimus on suoritettu kotikäynnin muodossa, jonka vuoksi se on käytännöllisistä syistä täytynyt rajoittaa käsittämään vain Helsingistä kotoisin olevat potilaat. Näiden osuus sosiaalineuvo- 
lan potilaistossa on noin $51 \%$. Kotikäynnit on pyritty järjestämään siten, että sama sosiaalihoitaja, joka potilaan neuvolassa käydessä on joutunut perehtymään hänen asioihinsa, on suorittanut myös jälkitiedustelun. Kaikki jälkitiedustelut suoritettiin touko-kesäkuussa 1953, observaatioajan vaihdellessa potilaiden kohdalla $1-3$ vuoteen.

Potilaiden haastattelussa noudatettiin määrättyä kaavaa, joskaan mitään muistiinpanoja ei haastattelun aikana tehty. Pyrkimyksenä oli saada potilaat kertomaan spontaanisti mahdollisimman paljon. Haastattelussa kiinnitettiin huomiota toimenpiteen potilaalle aiheuttamaan fyysilliseen vaivaan ja mahdollisiin toimenpidettä seuranneisiin psyykillisiin reaktioihin (omantunnonvaivat). Haastattelun päätarḳoituksena on kuitenkin ollut selvittää potilaiden suhtautumista keskeytyksen jälkeiseen hedelmöityksen ehkäisyyn sekä heidän reagointiaan mahdollisesti alkaneeseen tai alkavaan uuteen raskaudentilaan.

\section{Tulokset}

Taulukko 1 osoittaa aineiston jakautumisen keskeytysindikaatioiden mukaan. Eri indikaatioiden suhteelliset osuudet tässä materiaalissa poikkeavat suuresti niiden prosentuaalisesta osuudesta AA-indikaatioina koko maassa. Ne antavat samalla suurin piirtein oikean kuvan sosiaalineuvolan poikkeuksellisesta potilaistosta, jonka muodostavat lääketieteellisessä mielessä rajatapaukset (väsymys- ja heikkoustilat) sekä negatiivisten sosiaalisten tekijöiden rasittamat potilaat. Suhteellisen korkeat iän ja lapsiluvun keskiarvot eri indikaatioryhmissä ovat tälle potilasaineistolle myös tyypillisiä.

Taulukko 1. Keskeytysindikaatiot sekä keski-ikä ja lapsiluku eri indikaatioryhmissä.

\begin{tabular}{|c|c|c|c|}
\hline A ihe & Luku & $\begin{array}{c}\text { Ikä keski- } \\
\text { määrin }\end{array}$ & $\begin{array}{l}\text { Lapsiluku } \\
\text { keskimäär. }\end{array}$ \\
\hline$\ldots \ldots \ldots$ & 18 & 30,5 & 2,8 \\
\hline & 3 & 33,6 & 3,0 \\
\hline$\ldots \ldots$ & 18 & 36,3 & 3,6 \\
\hline tetriset taudit .... & 14 & 30,0 & 1,6 \\
\hline & 7 & 33,1 & 3,0 \\
\hline ikkoustilat & 40 & 34,0 & 4,3 \\
\hline Yhteensä & 100 & 32,9 & 3,1 \\
\hline
\end{tabular}

1. Mielitaudit $\ldots \ldots \ldots \ldots \ldots \ldots \ldots \ldots, 18$

2. Hermotaudit ................ 3

3. Sisätaudit $\ldots \ldots \ldots \ldots \ldots \ldots \ldots \ldots \ldots$

4. Gynegologis-obstetriset taudit $\ldots . .14$

5. Tuberkuloosi $\ldots \ldots \ldots \ldots \ldots \ldots \ldots, 7$

6. Väsymys- ja heikkoustilat ....... 40

Yhteensä 100 
Tiedusteltaessa potilaiden suhtautumista suoritettuun keskeytykseen kävi ilmi, että 73 piti sitä täysin oikeana ja ainoana mahdollisena ratkaisuna silloiseen pulmaansa. Nämä potilaat toivat haastattelijalle ilmi kiitollisuutensa siitä, että tämä oli auttanut heitä saamaan toiveensa läpi. He ilmoittivat myös uuden raskaudentilan sattuessa kääntyvänsä uudelleen neuvolan puoleen keskeytyksen saadakseen. Syyllisyydentunteista tai omantunnonvaivoista ei kukaan heistä sanonut kärsineensä. 27 potilasta piti keskeytystä luonnottomana toimenpiteenä, »jokaiselle naiselle vastenmielisenä ja vaikeana asiana», johon vain ehdottoman pakon edessä on taivuttava. 15:1lä näistä potilaista oli vakavampia syyllisyydentunteita ja heistä 4 ilmoitti katuvansa sitä, että olivat alistuneet toimenpiteeseen. Kaikki 27 sanoivat uuden raskauden sattuessa sairautensa uhallakin mieluummin kärsivänsä raskauden, synnytyksen ja lapsen aiheuttamat rasitukset kuin uudelleen ryhtyvänsä keskeytykseen. Heistä oli kaksi jo synnyttänyt lapsen keskeytyksen jälkeen ja yksi oli parhaillaan raskaana. Kenellekään potilaista ei keskeytyksestä ollut koitunut fyysillistä vammaa, vaan toimenpide oli jokaisen kohdalla sujunut ilman komplikaatioita. T a u lukko 2 osoittaa aineiston potilaiden suhtautumista mahdollisesti alkavaan uuteen raskauteen.

T a u lukko 3 selvittää potilaiden suhtautumista syntyvyyden säännöstelyyn ja heidän tässä mielessä käyttämiään ehkäisykeinoja. Tuloksia tarkasteltaessa on otettava huomioon, ettei yksikään aineiston potilaista kysyttäessä ilmoittanut toivovansa lasta. Tätä taustaa vasten on taulukon tuloksia pidettävä yllättävän

Taulukko 2. Potilaiden suhtautuminen mahdollisesti alkavaan raskaudentilaan

\begin{tabular}{|c|c|c|c|c|c|}
\hline Keskeytyksen aihe & Luku- & Avioliiton & Raska & den $\mathrm{s}$ & sattuessa \\
\hline & määrä & kesto v. & Lapsi & AA & Ei tiedä \\
\hline litaudit & 18 & 7,5 & 5 & 9 & 4 \\
\hline notaudit... & 3 & 7,0 & 1 & 2 & - \\
\hline taudit & 18 & 10,0 & 3 & 15 & - \\
\hline ekologis-obstetriset taudit & 14 & 7,0 & 4 & 10 & - \\
\hline erkuloosi & 7 & 9,0 & 2 & 5 & - \\
\hline mys- ja heikkc & 40 & 8,5 & 12 & 21 & 7. \\
\hline Yhteensä & 100 & 8,5 & 27 & 62 & 11 \\
\hline
\end{tabular}


Taulukko 3. Potilaiden käyttämät ehkäisymenetelmät.

Keskeytyksen aihe

Ehkäisykeinot

1. Mielitaudit $\ldots \ldots \ldots$

2. Hermotaudit .... 3

3. Sisätaudit $\ldots \ldots, \quad 18$

Lukumäärä

4. Gynekologis-obstetriset taudit ..... 14

5. Tuberkuloosi

6. Väsymys- ja heikkoustilat

$\begin{array}{cr}\text { Y........ } & 40 . \\ \text { Yhteensä } & 100\end{array}$

\section{Pes-} saari

2

$-$

2

-

2

7
Kon-

domi

6

$-$

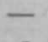

2

6

15
Coitus Oginointerr. Knauss

5 -

1

$$
-
$$

1 \\ $+$}

$-$

1

25
Huuh- Ei mitelut tään 14

- 2

9

9

4

20

48

huonoina. Vaikka olettaisimme, että osa niistä, jotka kieltävät käyttävänsä minkäänlaista ehkäisyä, ovat tehneet sen päästäkseen häveliäisyyssyistä puhumasta koko asiasta, eivät tulokset silti asiallisesti arvostellen paljon kaunistu. Vain 7 potilasta käyttää tehokasta ehkäisykeinoa (pessaari) ja 15 turvautuu välttävään keinoon (kondomi). Yli neljännes koko aineistosta käyttää epävarmoja tai hylättäviä menetelmiä ja lähes puolet potilaista eivät käytä mitään ehkäisykeinoja. Tälle holtittomuudelle kuvaavaa on, että tässä pienessä aineistossa mielitautiryhmän potilaat huolehtivat ylivoimaisesti parhaiten tästä järkeä ja harkintaa vaativasta asiasta!

Tavallisin syy siihen, ettei tuiki tarpeellisista ehkäisyneuvoista ole käyty lääkärissä tai avioliittoneuvolassa ottamassa selkoa, on saamattomuus. Tätä puolustellaan vetoamalla kotitöiden paljouteen sekä varattomuuteen ja häveliäisyyteen. Eletään päivä kerrallaan luottaen hyvään onneen ja siihen, ettei raskaus heti keskeytyksen jälkeen ala. 10 potilasta oli keskeytyksen jälkeen tullut uudelleen raskaaksi. Näistä oli 5 anonut uudelleen keskeytystä, joka oli myönnetty yhdelle. Kaksi ei ollut periaatteellisista syistä halunnut turvautua keskeytykseen ja 3 ei ollut kehdannut tulla neuvolaan niin pian uudelleen.

Tuloksia arvosteltaessa on otettava huomioon, että sosiaalineuvolan potilaiston muodostavat suurimmalta osaltaan yhteis- 
kunnan alimmista kerroksista kotoisin olevat, joiden keskuudessa oma-aloitteinen toiminta ja vastuuntunto eivät ole korkealle arvosteltavissa. Tästä syystä ei tämän pienen tutkimuksen tuloksia voida yleistää. Toisaalta on taas otettava huomioon, että juuri tutkimuksen kohteena oleville potilaille on neuvolassa erikoisesti tähdennetty hedelmöityksen ehkäisyn tärkeyttä ja korostettu sitä vaaraa, mihin he antautuvat, jos luottavat yksinomaan »varovaisuuteen» tai onneensa.

Huolimatta siitä, että aborttikysymyksestä ja syntyvyyden säännöstelystä on viime vuosien aikana paljon puhuttu myös julkisuủdessa, näyttää siltä, että vaaditaan vielä runsaasti valistustoimenpiteitä ennen kuin edes kipeimmässä tarpeessa olevat saadaan ymmärtämään vastuunsa. Raskaudenkeskeytyksen alistaminen palvelemaan lapsirajoitusta, sen rinnastaminen syntyvyydensäännöstelymenetelmiin ei ole lain pykälien eikä moraalin kannalta mahdollista.

Lääkärin kannalta katsoen on raskauden keskeyttäminen poikkeuksetta vastenmielinen toimenpide huolimatta siitä, että lain säätämät indikaatiot ovat eittämättömästi täytetyt. Ainoastaan tietoisuus siitä, että tuhotessaan juuri alkaneen elämän hän pelastaa jo kypsään ikään ehtineen ihmisen ja näin valitsee kahdesta pahasta pienemmän, saattaa hänet moraalisesti vakuuttuneeksi tekonsa oikeutuksesta. Silloin kun potilas saapuu toista tai kolmatta kertaa sairaalaan raskaudenkeskeytystä varten, muuttuu asia lääkärin kohdalla oleellisesti. Olkoonpa potilasta raskauden takia uhkaava vaara kuinka suuri tahansa, ei se muuta sitä asiaa, että lääkäri tuntee olevansa osallisena toiminnassa, joka ei ole oikein johdettu.

\section{Yhteenveto}

Aineisto käsittää 100 helsinkiläistä potilasta, joille vuosina 1950-1952 on suoritettu raskaudenkeskeytys. Näiden sadan sosiaalineuvolan potilaistosta sattumanvaraisesti valitun potilaan luona on suoritettu kotikäynti $1-3$ vuoden kuluttua keskeytyksestä tarkoituksena selvittää, miten potilaat ovat suhtautuneet raskau- 
denkeskeytykseen ja miten he ovat sen jälkeen huolehtineet syntyvyydensäännöstelystä.

Keskeytys oli kaikkien potilaiden kohdalla sujunut ilman komplikaatioita. 27 potilaalla on keskeytyksen jälkeen ollut omantunnon vaivoja ja syyllisyyden tunteita, ja he ilmoittivat kaikki uuden raskauden sattuessa mieluummin synnyttävänsä lapsen kuin alistuvansa keskeytykseen. Nämä potilaat käyttivät kaikki jonkinlaista ehkäisykeinoa - tosin 16 heistäkin turvautui coitus interruptukseen. Koko aineistosta oli ainoastaan 7:llä pessaari, 15 turvautui kondomiin, 30 käytti hylättäviä ehkäisykeinoja (coitus interruptus) ja 48 eli lähes puolet ei ollut ryhtynyt minkäänlaisiin toimenpiteisiin ehkäistäkseen ei-toivotun raskaudentilan alkamisen. 10 potilasta oli suoritetun keskeytyksen jälkeen tullut uudelleen raskaaksi. Näistä oli 5 anonut uutta keskeytystä, joka oli myönnetty yhdelle. Aineiston potilaista ei kukaan ollut keskeytyksen jälkeen halunnut lasta. 